\title{
ANALISIS PELAPISAN TEMBAGA TERHADAP LAJU KOROSI DAN STRUKTUR MIKRO GREY CAST IRON
}

\author{
Fitri Hardiyanti $^{1 *}$, Mochamad Yusuf Santoso ${ }^{2}$ \\ ${ }^{1}$ Teknik Perancangan dan Konstruksi Kapal,Politeknik Perkapalan Negeri Surabaya \\ email: fitridiyanti@gmail.com \\ ${ }^{2}$ Teknik Keselamatan dan Kesehatan Kerja,Politeknik Perkapalan Negeri Surabaya
}

diterima tanggal : 20 Maret 2018 disetujui tanggal : 10 Mei 2018

\begin{abstract}
Abstrak
Material besi tuang kelabu merupakan bahan yang banyak digunakan untuk aktivitas industri, termasuk industri rumah tangga. Bahan ini memiliki titik leleh yang rendah, sehingga mudah untuk dibentuk, bahkan pada cetakan yang rumit. Masalah utama pada logam untuk industri adalah korosi. Beberapa teknik digunakan untuk menghalangi korosi.salah satu caranya adalah pelapisan logam, seperti elektroplating. Teknik ini akan diterapkan pada besi tuang kelabu untuk melindungi dari pengaruh lingkungan, seperti hujan atau air laut. Makalah ini akan melakukan kajian pengaruh waktu perendaman dan konsentrasi larutan elektroplating untuk besi tuang kelabu. Hasil percobaan menunjukkan bahwa semakin tinggi konsentrasi larutan dan semakin lama waktu perendaman, laju korosi akan melambat. Pengujian struktur mikro menunjukkan hasil bahwa bahan besi tuang kelabu akan mengalami perubahan struktur mikro setelah korosi.
\end{abstract}

Kata kunci : Besi tuang kelabu, laju korosi, elektroplating, konsentrasi larutan, uji perendaman

\begin{abstract}
Metals are material that widely used in industrial activity, including home industry. However, the main problem in metal industry is corrosion. Some techniques are utilized for corrosion inhibition. One of them are metal coating. Grey cast iron is one of cast iron which has low melting temperature. It is easily formed, even for complicated mold. This metal has potential for corrosion because it will contact environment, such as rain or sea water. Thus, grey cast iron needs corrosion protection. One of metal coating techniques is electroplating. This paper will study about the influence of immersion time and solution concentration in electroplating technique for grey cast iron. Experimental result show that the higher solution concentration and the longer immersion time, the corrosion rate will decelerate. Microstructure testing shows that corroded metal has rougher structure than uncorroded one.
\end{abstract}

Keywords : grey cast iron, corrosion rate, electroplating, solution concentration, immersion test

\section{PENDAHULUAN}

Logam menjadi kebutuhan pada berbagai macam industri, termasuk sektor industri rumah tangga. Salah satu permasalahan penggunaan logam untuk industri yaitu korosi [1]. Hal ini tentu saja akan memberikan hambatan untuk kegiatan industri. Korosi merupakan kerusakan atau degradasi dari material akibat reaksi reduksioksidasi (redoks) antara bahan dengan berbagai zat yang ada di lingkungan sehingga menghasilkan senyawa yang tidak diinginkan [2]. Contoh paling umum dari korosi adalah pengkaratan pada besi. Berbagai macam cara digunakan untuk mencegah terjadinya korosi. Salah satu tekniknya adalah dengan melapisi logam menggunakan krom [3].

Grey cast iron, atau disebut besi tuang kelabu memiliki sifat sebagai logam yang sangat mudah untuk melebur. Sifat ini menguntungkan padaproses peleburan karena menghemat bahan bakar. Besi ini juga sangat mudah untuk dibentuk, walaupun dengan cetakan yang rumit. penerapan paling banyak untuk material ini adalah knalpot 
sepeda motor dan katup pada pompa air. Seperti halnya logam yang mengandung besi lainnya, besi tuang kelabu berpotensi untuk korosif. Hal ini karena pada penggunaannya, bahan ini berhadapan langsung dengan cuaca, seperi hujan atau air laut, yang menjadi penyebab utama terjadinya korosi [4].

Pelapisan krom merupakan pelapisan logam dengan teknik elektroplating. Berbagai jenis logam seperti besi, baja, dan tembaga dapat dikenai perlakuan teknik ini. Teknik ini dilakukan dengan menambahkan logam lain sebagai pelapis. Pelapisan krom juga dapat dilakukan untuk bahan plastik atau bahan non-logam lain, dengan syarat material tersebut harus dicat terlebih dahhulu menggunakan cat yang mengandung logam untuk membangkitkan listrik [5].

Pelapisan krom pada besi tuang kelabu pernah dilakukan [6-8]. Namun, masih belum didapatkan informasi tentang pengaruh konsentrasi larutandan lama waktu perendaman elektroplating untuk menghasilkan pelapisan krom yang bagus. Kedua parameter ini juga masih menjadi rahasia bagi pemilik industri elektroplating. Penelitian ini akan menjelaskan tentang pengaruh waktu perendaman dan konsentrasi larutan elektroplating. Anaslisa akan dilakukan terhadap laju korosi dan struktur mikro material besi tuang kelabu.

\section{METODEPENELITIAN}

A. Persiapan Material

Bahan yang akan digunakan untuk pelapisan krom adalah besi tuang kelabu. Besi tuang kelabu banyak sekali digunakan karena keunggulannya. Sifat unggul dari logam ini antara lain: mudah diproses, harga relatif murah, tahan aus atau gesekan, faktor redam dan kekuatan tekan yang tinggi [4].

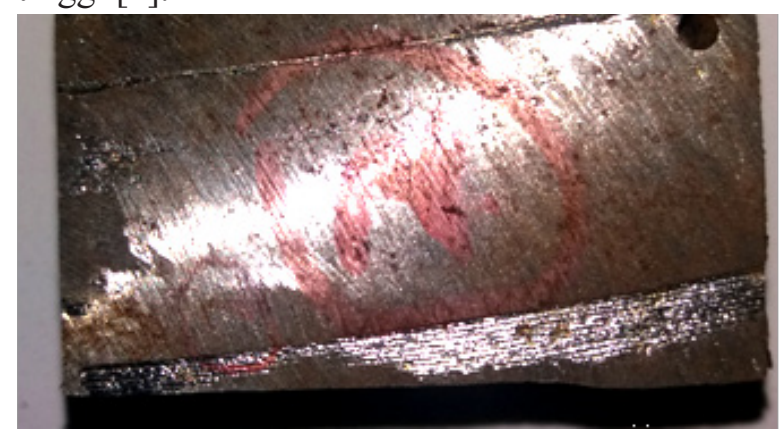

Gambar 1. Contoh Spesimen Besi Tuang Kelabu
Ukuran dari spesimen pada penelitian ini adalah $50 \mathrm{~mm}$ (panjang) x $30 \mathrm{~mm}$ (lebar) x $25 \mathrm{~mm}$ (tebal). Contoh dari spesimen logam ditunjukkan pada Gambar 1.

\section{B. Elektroplating}

Elektroplating merupakan salah satu teknik pelapisan logam untuk mencegah terjadinya korosi dengan cara pengendapan pada elektroda. Tujuannya untuk membentuk permukaan dengan sifat atau dimensi yang berbeda dari logam dasarnya [5].

Teknik elektroplating merupakan teknik elektrolisa yang menggunakan bejana sel elektrolisa berisi larutan elektrolit. Skema proses elektroplating ditunjukkan pada Gambar 2. pada larutan tersebut, minimal terdapat dua elektroda yang tercelup. setiap elektroda dihubungkan dengan arus listrik untuk menjadi kutub positif (anoda) dan kutub negatif (katoda) [5].

Prinsip dasar pelapisan logam dengan teknik elektroplating adalah menempatkan ionion logam dan elektrom pada logam yang dilapisi. Ion-ion tersebut berasal dari anoda dan eletrolit yang digunakan. Arus listrik akan mengalirkan elektron melalui anoda menuju katoda. Persiapan permukaan logam yang akan dilapisi perlu dilakukan dengan tujuan untuk meningkatkan daya ikat antara lapisan dan spesimen [5]. Material pelapis yang digunakan adalah tembaga dan larutan elektrolitnya menggunakan larutan tembaga sulfat (CuSO4). Gambar 3 menunjukkan peralatan yang digunakan untuk proses pelapisan logam.

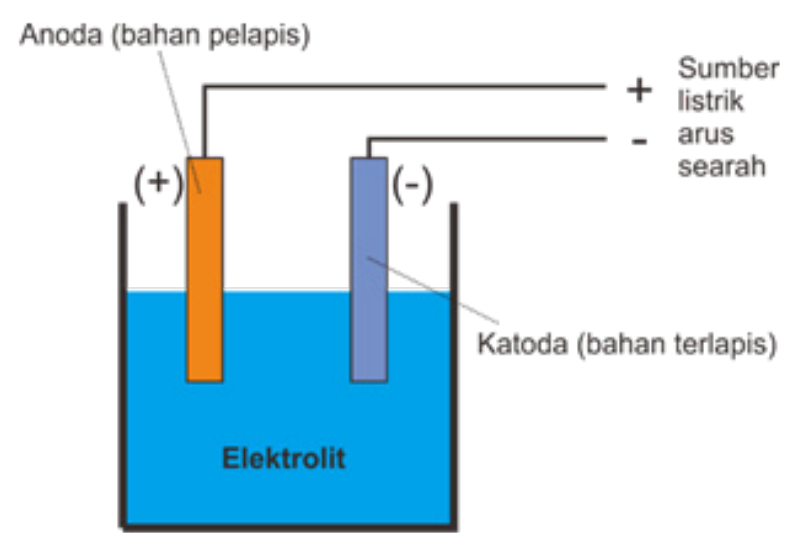

Gambar 2. Skema Proses Elektroplating [5] 
Terdapat tiga variasi nilai konsentrasi larutan dengan waktu perendaman tetap dan tiga variasi waktu perendaman dengan satu konsentrasi tetap. Masing-masing variasi diwakili oleh tiga spesimen. Sehingga total spesimen yang digunakan berjumlah 18 (delapan berlas).

Tabel 1. Variasi spesimen

\begin{tabular}{ccccc}
\hline $\begin{array}{c}\text { Nomor } \\
\text { Spesimen }\end{array}$ & $\begin{array}{c}\text { Konsentrasi } \\
\text { CuSO4 (\%) }\end{array}$ & $\begin{array}{c}\text { Waktu } \\
\text { (menit) }\end{array}$ & $\begin{array}{c}\text { Massa } \\
\text { (grams) }\end{array}$ & $\begin{array}{c}\text { Volume } \\
\text { (cm3) }\end{array}$ \\
\hline 1 & $70 \%$ & 90 & 208.1302 & 27.76874 \\
2 & $70 \%$ & 90 & 193.9187 & 20.95632 \\
3 & $70 \%$ & 90 & 210.5441 & 26.81024 \\
4 & $50 \%$ & 90 & 189.8993 & 25.70906 \\
5 & $50 \%$ & 90 & 213.0327 & 31.3158 \\
6 & $50 \%$ & 90 & 207.4928 & 29.80027 \\
7 & $30 \%$ & 90 & 196.2182 & 28.75635 \\
8 & $30 \%$ & 90 & 180.3598 & 26.23556 \\
9 & $30 \%$ & 90 & 180.9015 & 29.42529 \\
10 & $50 \%$ & 120 & 199.9050 & 28.52677 \\
11 & $50 \%$ & 120 & 190.3201 & 33.65517 \\
12 & $50 \%$ & 120 & 172.9842 & 28.68964 \\
13 & $50 \%$ & 90 & 191.7462 & 23.64613 \\
14 & $50 \%$ & 90 & 185.1865 & 31.88086 \\
\hline 15 & $50 \%$ & 90 & 160.0659 & 22.8735 \\
& & & & \\
\hline & & & & \\
\hline & & & & \\
\hline
\end{tabular}

Gambar 3. Instrumen Elektroplating

\section{Proses Korosi}

Korosi dapat dikatakan sebagai penurunan kualitas logam. Korosi dapat terjadi akibat reaksi elektrokimia antara logam dengan lingkungan. Salah satu kondisi lingkungan yang sering mengakibatkan korosi pada besi adalah air laut. Air laut mengandung berbagai macam garam, dengan prosentase garam terbesar adalah $\mathrm{NaCl}$ [9].

Untuk menghasilkan korosi pada material spesimen, dilakukan uji perendaman. Spesimen direndam dalam larutan garam $(\mathrm{NaCl})$ selama 8 hari, yang ditunjukkan pada Gambar 4. Larutan garam digunakan karena larutan ini merupakan media korosif [9]. Hasil proses perendaman kemudian ditimbang untuk diketahui massa setelah mengalami proses korosi.

\section{Perhitungan Laju Korosi}

Laju korosi dengan immersion test dilakukan berdasarkan kehilangan berat. Metode kehilangan berat dilakukan dengan menghitung selisih antara berat awal dan berat akhir yang terjadi setelah beberapa waktu pencelupan [10].

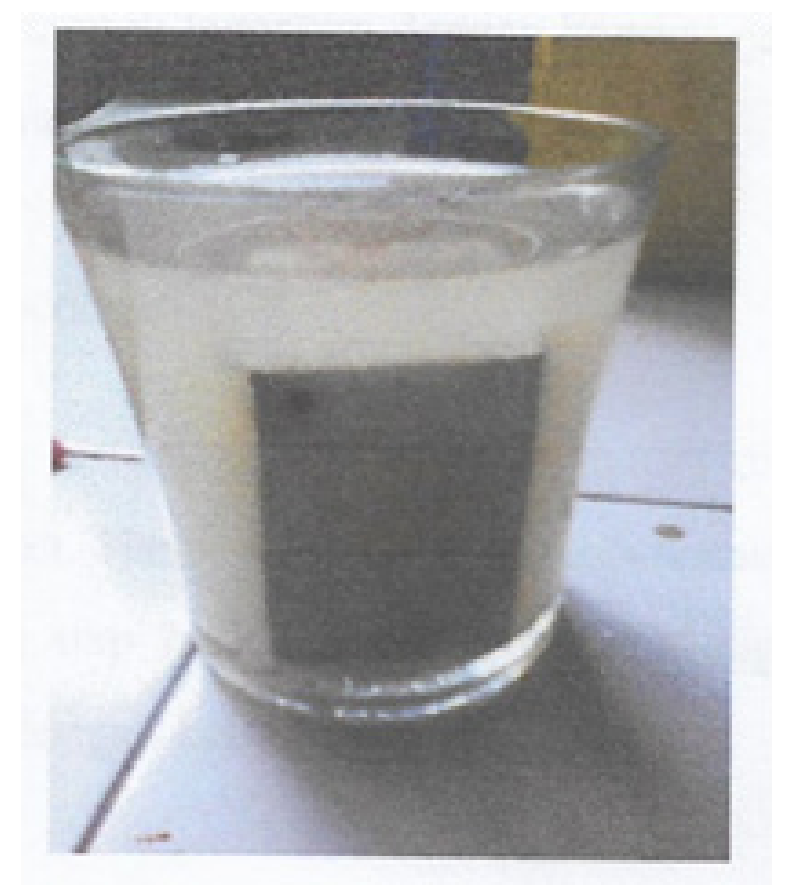

Gambar 4. Proses Perendaman Spesimen pada Larutan $\mathrm{NaCl}$ 


$$
\mathrm{CR}=(87,6 \times \mathrm{W}) /(\mathrm{D} \times \mathrm{A} \times \mathrm{T})
$$

dimana:

$\mathrm{CR}=$ laju korosi (mmpy)

$\mathrm{W}=$ berat yang hilang (gram)

$\mathrm{D}=$ density benda uji korosi $(\mathrm{gram} / \mathrm{cm} 3)$

$\mathrm{A}=$ luas permukaan (in2)

$\mathrm{T}=$ waktu, hour (jam).

\section{HASIL DAN PEMBAHASAN}

Massa dari spesimen yang sudah mengalami korosi ditunjukkan pada Tabel 2 . Dengan menggunakan informasi kehilangan berat, diperoleh nilai laju korosi. Berdasarkan hasil perhitungan, didapatkan grafik hubungan konsentrasi larutan terhadap laju korosi yang ditunjukkan pada Gambar 5. Sedangkan Gambar 6 menunjukkan grafik hubungan antara lama perendaman proses elektroplating dengan korosi.

Gambar 5 menunjukkan grafik nilai laju korosi berdasarkan perubahan konsentrasi CuSO4. Grafik tersebut menunjukkan bahwa semakin tinggi konsentrasi larutan $\mathrm{CuSO} 4$, maka laju korosi akan semakin menurun. Pada Gambar 6, ditunjukkan bahwa semakin lama waktu perendaman, maka laju korosi akan semakin rendah.

Tabel 2. Hasil Perhitungan Laju Korosi

\begin{tabular}{ccccc}
\hline $\begin{array}{c}\text { Nomor } \\
\text { Spesimen }\end{array}$ & $\begin{array}{c}\text { W1 } \\
\text { (gram) }\end{array}$ & $\begin{array}{c}\text { W8 } \\
\text { gram) }\end{array}$ & $\begin{array}{c}\text { W } \\
\text { (gram) }\end{array}$ & $\begin{array}{c}\text { Cr } \\
\text { (mmpy) }\end{array}$ \\
\hline 1 & 208.1302 & 208.1281 & 0.0021 & $2.137 \mathrm{E}-06$ \\
2 & 193.9187 & 193.9152 & 0.0035 & $3.396 \mathrm{E}-06$ \\
3 & 210.5441 & 210.5410 & 0.0031 & $2.998 \mathrm{E}-06$ \\
4 & 189.8993 & 189.8900 & 0.0093 & $9.936 \mathrm{E}-06$ \\
5 & 213.0327 & 213.0235 & 0.0092 & $9.644 \mathrm{E}-06$ \\
6 & 207.4928 & 207.4832 & 0.0096 & $9.959 \mathrm{E}-06$ \\
7 & 196.2182 & 196.2046 & 0.0136 & $1.470 \mathrm{E}-05$ \\
8 & 180.3598 & 180.3407 & 0.0191 & $2.158 \mathrm{E}-05$ \\
9 & 180.9015 & 180.8896 & 0.0119 & $1.424 \mathrm{E}-05$ \\
10 & 199.9050 & 199.9022 & 0.0028 & $2.965 \mathrm{E}-06$ \\
11 & 190.3201 & 190.3181 & 0.0020 & $2.408 \mathrm{E}-06$ \\
12 & 172.9842 & 172.9817 & 0.0025 & $3.099 \mathrm{E}-06$ \\
13 & 191.7462 & 191.7390 & 0.0072 & $7.622 \mathrm{E}-06$ \\
14 & 185.1865 & 185.1785 & 0.0080 & $9.634 \mathrm{E}-06$ \\
15 & 160.0659 & 160.0570 & 0.0089 & $1.059 \mathrm{E}-05$
\end{tabular}

$\begin{array}{lllll}16 & 200.6378 & 200.6198 & 0.0180 & 1.982 \mathrm{E}-05 \\ 17 & 156.0315 & 156.0188 & 0.0127 & 1.632 \mathrm{E}-05\end{array}$

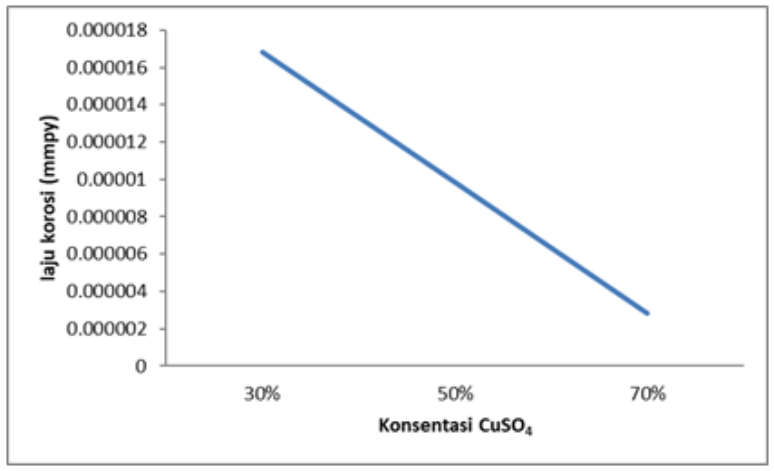

Gambar 5. Grafik Laju Korosi Terhadap Konsentrasi $\mathrm{CuSO} 4$

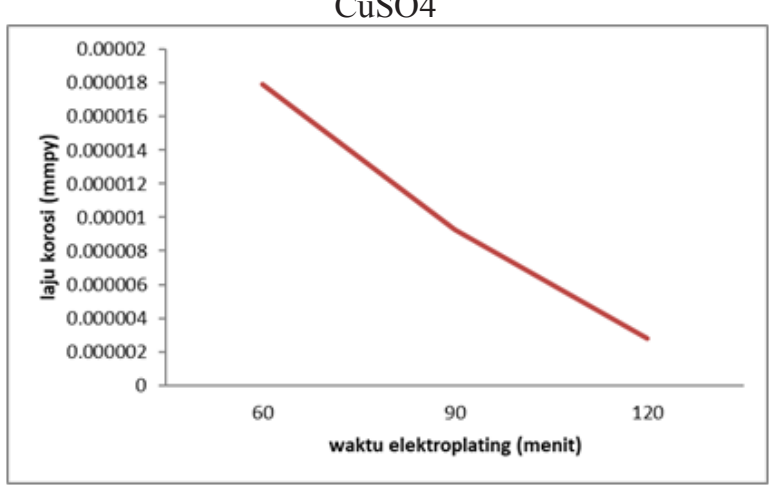

Gambar 6. Grafik Laju Korosi Terhadap Waktu Elektroplating

Hasil perhitungan ini menunjukkan bahwa peningkatan konsentrasi larutan tembaga sulfat akan meningkatkan ketahanan korosi besi tuang kelabu. Begitu juga dengan meningkatkan waktu perendaman, material akan lebih lambat mengalami korosi jika semakin lama direndam. Namun, tentu saja peningkatan dua parameter pada penelitian ini akan berdampak pada sifat mekanis lainnya, Sehingga diperlukan penelitian lebih lanjut untuk mendapatkan formulasi konsentrasi larutan tembaga sulfat dan waktu perendaman yang tepat agar mendapatkan hasil krom yang dapat melindungi logam dari korosi secara maksimal dan dapat mempertahankan sifat unggul dari material.

Setelah didapatkan nilai laju korosi untuk tiap specimen, tahapan berikutnya adalah melakukan pengujian struktur mikro. Pengujian struktur mikro specimen dilakukan dengan mikroskop elektron. Tujuan dari pengujian struktur 
mikro adalah mengetahui bagaimana struktur mikro dari spesimen yang mengalami korosi dan tidak mengalami korosi.

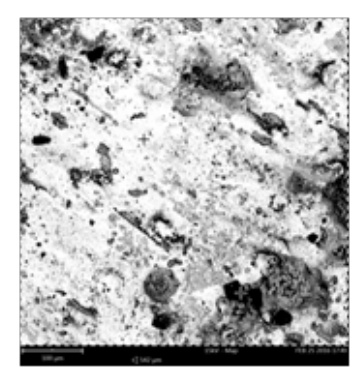

sampel 1

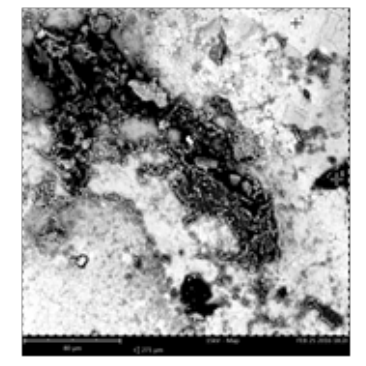

sampel 2

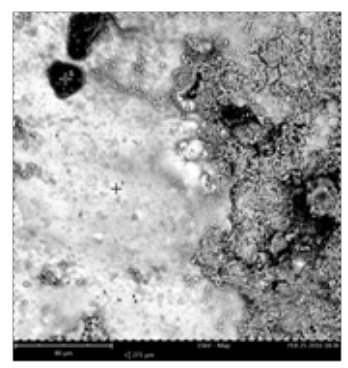

sampel 3

Gambar 7. Hasil pengujian mikro spesimen yang mengalami korosi

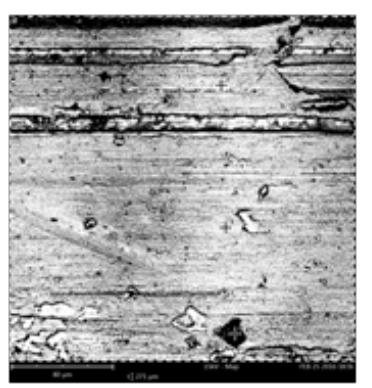

Gambar 8. Hasil pengujian mikro spesimen yang tidak mengalami korosi

Hasil pengujian struktur mikro untuk spesimen yang mengalami korosi ditunjukkan pada Gambar 7. Terdapat tiga buah spesimen uji dengan perbesaran 1000 kali. Sedangkan untuk material yang tidak mengalami korosi, hasil pengujian mikro ditunjukkan pada gambar 8 . Berdasarkan hasil pengujian mikro, didapatkan hasil bahwa spesimen yang mengalami korosi memiliki permukaan yang lebih kasar daripada spesimen yang tidak mengalami korosi. Hal ini menunjukkan bahwa material yang tidak mengalami korosi memiliki struktur yang lebih teratur daripada yang tidak mengalami korosi.

\section{KESIMPULAN}

Berdasarkan hasil percobaan dan perhitungan, didapatkan bahwa konsentrasi larutan dan waktu perendaman pada proses elektroplating berpegaruh terhadap laju korosi. Semakin tinggi konsentrasi larutan, maka semakin rendah laju korosinya. Untuk waktu perendaman, laju korosi akan semakin lambat jika waktu perendaman semakin lama. Hasil pengujian struktur mikro menunjukkan material yang mengalami korosi memiliki struktur yang lebih tidak teratur daripada material yang tidak mengalami korosi.

\section{DAFTAR PUSTAKA}

[1] Topayung, D., Pengaruh Arus Listrik Dan Waktu Proses Terhadap Ketebalan Dan Massa Lapisan Yang Terbentuk Pada Proses Elektroplating Pelat Baja. Jurnal Ilmiah Sains, 2011. 11(1): p. 97-101.

[2] Haryono, G., et al. Ekstrak bahan alam sebagai inhibitor korosi. in Prosiding Seminar Nasional Teknik Kimia “Kejuangan”(1). 2010.

[3] Mubin, A., Uji Pemanfaatan Teknologi Elektroplating Pada Produk Pandai Besi Sebagai Upaya Peningkatan Kualitas dan Daya Saing. Jurnal Teknik Industri, 2001. 2(1).

[4] Subarmono, S., R. Rusiyanto, and S.W. Siswanto, Pengaruh pemanasan paska pengelasan terhadap sifat mekanis besi tuang kelabu. Jurnal Mesin dan Industri, 2007. 4(1): p. 89-95.

[5] Suarsana, K., Pengaruh waktu pelapisan nikel pada tembaga dalam pelapisan khrom dekoratif terhadap tingkat kecerahan dan ketebalan lapisan. Jurnal Ilmiah Teknik Mesin Cakram, 2008. 2(1): p. 48-60.

[6] Romijarso, T.B., Perbandingan Kekerasan Dan Ketahanan Abrasi Proses Pelapisan Kromisasi, Boronisasi Dan Vanadisasi Pada Besi Cor Kelabu. Metalurgi, 2017. 28(3): p. 167-176. 
[7] Sukrawan, Y., Analisis Variasi Waktu Proses Hard Chrome Terhadap Kekerasan Dan Ketebalan Lapisan Pada Besi Cor Kelabu. Torsi, 2016. 1(1).

[8] Umardani, Y., D.B. Wibowo, and A. Suprihanto, Perbaikan Sifat Mekanis Besi Cor Kelabu Dengan Penambahan Unsur Crom Dan Tembaga. 2005.

[9] Ludiana, Y. and S. Handani, Pengaruh Konsentrasi Inhibitor Ekstrak Daun Teh (Camelia Sinensis) Terhadap Laju Korosi Baja Karbon Schedule 40 Grade B Erw. Jurnal Fisika Unand, 2012. 1(1).

[10] Pattireuw, K.J., F.A. Rauf, and R.C.A. Lumintang, Analisis laju korosi pada baja karbon dengan Menggunakan air laut dan H2SO4. Jurnal Online Poros Teknik Mesin Unsrat, 2013. 2(1). 